\title{
Enterprise performance indicators and their use for strategic management - empirical evidence in globalized word
}

\author{
Marta Nosková ${ }^{*}$ \\ ${ }^{1}$ University of West Bohemia, Faculty of Economics, Department of Business Administration and \\ Management, Univerzitní 8, 30100 Plzeň, Czech Republic
}

\begin{abstract}
.
Research background: Indicators of enterprise performance has been globally discussed for decades. There are many ways to assess the performance of enterprises, some are general, and some are specifically tailored for enterprise's needs. Yet, this issue can be seen from other, empirical perspective: what aspects (indicators and their values) should enterprises focus on, in order to improve their performance in globalized word.

Purpose of the article: The aim of this article is to examine the set of indicators (i.e. their values) in order to find out which ones can affect the performance indicators, thus the enterprise performance itself. This finding could help the enterprise's management with strategic decisions regarding future objectives.

Methods: This research adopted quantitative approach based on the analysis of dataset downloaded from Albertina - Gold edition. Twelve selected indicators describing 2338 enterprises are statistically tested in order to accept or reject the hypothesis of their statistical interdependence towards selected performance indicators (ROE, ROS).

Findings \& Value added: The findings of this preliminary research indicate that there are few indicators (such as Total Debt or Working Capital), which correlate with performance indicators. These results are presented and discussed in the paper, together with the possible future research.
\end{abstract}

Keywords: performance indicators; strategic management

JEL Classification: $L 21 ; M 16$

\footnotetext{
${ }^{*}$ Corresponding author: mnosk@kpm.zcu.cz
} 


\section{Introduction}

Performance of enterprises together with performance management is widely discussed subject. Simple definition by Cokins [1, p. 9] states that performance management means "translation of plans into results-execution". The traditional approach to measurement of company's performance can be characterized by the following interrelated indicators: effectiveness, efficiency, quality, productivity, quality of work life, innovation, and profitability/budgetability [2].

Generally, enterprise performance can be assessed by using traditional financial indicators (in absolute or relative numbers) or by using some special models covering different areas at once, whether it is well-known Balanced Scorecard methodology [3], or other models covering area such as social benefits or sustainability of enterprises.

As stated by Cicea et al. [4], most studies dealing with the performance of enterprises, focus on organisational level, and try to explain the relationship of its performance and its internal environment factors, or with a combination of internal and external factors. The authors themselves point out that these studies are useful for entrepreneurs in their efforts to increase business performance. Escribá-Esteve et al. [5] point out that the identification of factors that affect the performance of the enterprise is an important goal of research in the field of strategic management.

Today, measuring performance of the enterprises can take many forms, some researchers use financial indicators in absolute form [6-8] or in relative form $[5,9,10]$. Financial indicators predominate, due to the easier availability of data. For example, Cataldo et al. [7] selected Income, Costs, Net Income, Fixed Capital and Total Assets as performance indicators, similar to Ausloos et al. [6], who used Sales and Tangible Assets. Skokan et al. [8] focused on Turnover, Costs, Profit, EVA, Investments and Period of arranged contracts. Cicea et al. [4] focused on Value added. Another group of authors use ratio indicators such as $\operatorname{ROA}[5,10,11]$, ROE [12], ROS [13], or even more complex indicators such as IN99 [10] or Tobin's Q, which is based on the market value of the company [14].

Research on performance determinants focuses on various explanatory indicators. Ausloos et al. [6] focuse on the impact of investment strategies on the company's performance. Alpkan, Yilmaz, and Kaya [15] demonstrated the impact of market orientation and planning flexibility on business performance. Cataldo et al. [7] confirm the relationship between the performance of the company and its ICT assets. Escribá-Esteve et al. [5] examine how this performance is influenced by the characteristics of top management team. A large amount of research is conducted on the topic of gender management, i.e. how business performance can be affected by the representation of women in business management [11-14]. Skokan et al. [8] confirm the positive impact of the existence of strategic planning in the organization on its performance (specifically in the case of micro, small and medium enterprises), as well as Śvárová and Vrchota [10], who showed that companies with a clearly defined strategy have better financial results. Cicea et al. [4] examine a number of determinants that may affect the performance of small and medium-sized enterprises (SMEs). Similar to Anggadwita and Mustafid [16], who focused on 4 areas: Entrepreneurial aspect, Competence of Human Resource, Innovativeness and Sustainability, and demonstrated that Entrepreneurial aspect and Competence of Human Resource affect company performance.

This paper aims to examine the set of indicators (i.e. their values) in order to find out if there exists any statistical relationship between them and selected performance indicators (ROE, ROS). This finding could indicate on what indicators should be the enterprise's management focused on in strategic decisions in order to improve its performance in globalized word. 


\section{Methodology}

\subsection{Data}

This research adopted quantitative approach. The dataset was downloaded from Albertina Gold edition [17] for the year 2018 and only those enterprises meeting given conditions were included. The conditions were determined in order to ensure, that research would contain only micro and small sized enterprises. This decision could be seen as incorrect considering the paper should focus on enterprise performance indicators and their use for strategic management, however this preliminary research should only test the idea of the interrelation between enterprise performance and other facts, thus the whole statistical population of these small-sized enterprises was considered as better data set for finding these relationships, than just sample of some selected enterprises from statistical population of medium-sized or large enterprises. And on top of that, there is no denying that the strategical decisions are also important for these micro and small-sized enterprises.

The conditions were following: enterprises have 50 employees or less, their turnover ranges from $1 \mathrm{mil}$. CZK to 200,000 mil. CZK, all legal forms except for non-profit organizations, and their place of business is anywhere in the Czech Republic except for Prague. The last condition results from the fact, that the actual place of business is important for the research and in the case of Prague, it cannot be determined with certainty, that the registered enterprise actually do its business there. These condition met 2338 enterprises located in the Czech Republic, however only 2155 enterprises were analysed, because some data were deleted due to extreme values of some indicators, or missing and wrong data.

Most enterprises are seated in South Moravian region (497), Central Bohemian region (232), Královéhradecký region (212), and Moravian-Silesian region (208). As for the number of employees, the enterprises with 3 employees (1042) prevail, followed by those with 15 employees (387) and 7 employees (355). Regarding the turnover, it mostly ranges from 1 to 10 mil. CZK (1263).

\subsection{Indicators}

To analyse the relationship between performance of the enterprises and other factors, the data for following indicators were obtained for each analysed company: GDP of the home region (GDP-REG), GDP of NACE group (GDP-NACE), number of employees (N.EMP), number of years in business (N.YEARS), registered capital (REG.CAP.), turnover (TURNOVER), payment index (PAYMENT.IN.), current assets (CURR.ASSETS), equity (EQUITY), trade payables (TR.PAYABLES), total debt (TOT.DEBT), working capital (WORK.CAP.), Return on equity (ROE) and Return on sales (ROS).

As indicators of enterprise performance ROE, and ROS were selected. As mentioned in the introduction, the enterprise's performance can be measured in various ways, mostly by using financial indicators. Some authors prefer market-based measures, for example Tobin's Q [14, 18], others accounting-based measures, such as return on assets (ROA), return on equity (ROE) or return on sales (ROS) [13]. In this paper, several types of enterprises were examined, most of which are not listed public limited companies. Thus, market-based measures were not available, and ROE, as the ratio of the enterprise net profit and capital invested by the owner (EBT/Equity), and ROS, as the ratio of the enterprise net profit and sales (EBT/Sales), have been selected as the most appropriate measurements of enterprise performance.

Other indicators were selected due to their availability and logical presumption, that there could be some relationship between them and performance indicators. 


\subsection{Methods}

Simple statistical tools such as the mean, minimal and maximal value, median, and standard deviation were used to describe the dataset.

Then data were tested for normality using Kolgomor-Smirnov test, which proved, that data does not have a normal distribution. Thus it was necessary to use non parametric test in order to find relationships between indicators. The correlation matrix based on the calculation of Spearman's correlation coefficients was compiled. All calculations were performed using the program STATISTICA 12 StatSoft CR, s. r. o.

\section{Results and discussion}

At first values of average, median, minimum, maximum and standard deviation were calculated. Their results revealed few extreme values or error in data, which had to be excluded from the calculation. Table 1 shows descriptive statistics for the final statistical sample (mostly $n=2155$ out of the original 2338 ).

From the descriptive statistics, it can be observed, that standard deviation of GDP (of region or of NACE) is not significant. The number of employees was determined in advance with a maximum of 50 and minimum 0 . The reason why there is value 3 as minimum is that The Bisnode Database works only with intervals and their centres. In terms of age, the average value was 13.6 years (median 13) with the maximum being 41 . This relatively low age of Czech enterprises (for example in comparison to the Romania, where the mean value in 2014 was 56.77 years [13]) is caused by the transformation of Czech economy in early 1990 (after the collapse of communist regime). Then many state enterprises changed their form, and even more enterprises were founded. As for registered capital, the value differs significantly, however the value of 200,000 million CZK is the median. Turnover minimum value was determined in advance as 1 mil. CZK (to ensure that only existing enterprises are part of the research). Payment index is related to enterprise's ability to pay their own debts and can have a value between 0 and 121 (zero means that enterprise pays its debts in time, 121 means that it pays more than 121 days after deadline). Other indicators are common indicators derived directly or indirectly from Balance Sheet or Profit and Loss Statement. 
Table 1. Descriptive statistics of micro and small enterprises in the Czech Republic in 2018 ( $\mathrm{n}=$ $2155)$.

\begin{tabular}{|c|c|r|r|r|r|r|}
\hline Variable & $\mathrm{n}$ & Average & \multicolumn{1}{c|}{ Median } & Minimum & Maximum & $\begin{array}{c}\text { St. } \\
\text { deviation }\end{array}$ \\
\hline $\begin{array}{c}\text { GDP (in CZK per } \\
\text { capita) of the } \\
\text { Home Region }\end{array}$ & 2155 & $374,659.0$ & $378,646.5$ & $293,028.8$ & 423,101 & 33,182 \\
\hline $\begin{array}{c}\text { GDP (mil. CZK) of } \\
\text { NACE Group }\end{array}$ & 2155 & $116,485.7$ & $106,678.0$ & 639.0 & 360,797 & 80,536 \\
\hline $\begin{array}{c}\text { Number of } \\
\text { Employees }\end{array}$ & 2155 & 9.6 & 3.0 & 3.0 & 37 & 10 \\
\hline $\begin{array}{c}\text { Number of Years } \\
\text { in Business }\end{array}$ & 2155 & 13.6 & 13.0 & 1.0 & 41 & 8 \\
\hline $\begin{array}{c}\text { Registered Capital } \\
\text { (CZK) }\end{array}$ & 2141 & $955,810.0$ & $200,000.0$ & 1.0 & $85,763,000$ & $4,567,119$ \\
\hline $\begin{array}{c}\text { Turnover (mil. } \\
\text { CZK) }\end{array}$ & 2155 & 19.3 & 9.0 & 1.0 & 199 & 26 \\
\hline Payment Index & 2155 & 6.1 & 0.0 & 0.0 & 121 & 16 \\
\hline $\begin{array}{c}\text { Current Assets } \\
\text { (mil. CZK) }\end{array}$ & 2155 & $6,798.7$ & $2,502.0$ & $-1,068.0$ & 214,952 & 12,581 \\
\hline Equity (mil. CZK) & 2155 & $5,408.0$ & $1,068.0$ & $-17,545.0$ & 487,427 & 17,469 \\
\hline $\begin{array}{c}\text { Trade Payables } \\
\text { (mil. CZK) }\end{array}$ & 1069 & $2,581.4$ & 697.0 & -139.0 & 71,980 & 5255 \\
\hline Total Debt (\%) & 2155 & 103.3 & 62.3 & -144.2 & 59,575 & 1292 \\
\hline $\begin{array}{c}\text { Working Capital } \\
\text { (mil. CZK) }\end{array}$ & 2155 & $2,432.0$ & 539.0 & $-45,738.0$ & 62,600 & 7176 \\
\hline ROE (\%) & 2155 & 23.3 & 17.4 & $-8,937.5$ & 9400 & 548 \\
\hline ROS (\%) & 2155 & -15.8 & 1.6 & $-4,320.0$ & 827 & 177 \\
\hline
\end{tabular}

Secondly, data were tested in order to prove/disprove their normality. The results showed, that normality could not be confirmed, thus the relation between performance indicators and other selected indicators was tested only using Spearman's rank correlation coefficient. Results are shown in table 2 .

Interestingly, most of the resulted values are statistically significant on level of significance $\mathrm{p}<0.05$ (marked as $*$ ). It is logical, because almost whole population of small and micro enterprises was tested (except for data deleted due to their incompleteness or error).

The most interesting results are in the columns/rows related to ROE and ROS. The strongest result can be found between ROS and Total debt $(-0.41)$, which is notable, because these two indicators are very different and this correlation cannot be caused due to the similarity of constructed indicators. This would mean that the higher the company's Total Debt is, the lower is ROS (but vice versa, the higher ROS is, the lower is the Total Debt, which seems like a more logical explanation). Another interesting result is the value 0.39 of correlation coefficient between ROS and Equity, which suggest that more equity enterprise has, more successful is in terms of ROS (or vice versa, more sales, more equity). Also, positive correlation was found between ROS and Working Capital (0.33) as well as Current Assets (0.26). The rest of the indicators (in terms of ROS) have the value of correlation coefficient in the interval $(-0.2 ; 0.2)$. It can be pointed out, that no correlation was found between ROS and GDP (regional, nor NACE), Number of years in business, Registered Capital as well as Trade Payables. 
Regarding ROE, almost all indicators have the value of correlation coefficient between 0.2 and 0.2 . The strongest relationship between ROE and other indicator is found in Number of years in business, its correlation coefficient has value of -0.32 . However, this relationship cannot be logically explained (the older the enterprise is, the lower the value of ROE is), thus it could be only coincidence. No correlation was found between ROE and GDP (regional, nor NACE), Number of employees, Turnover, Payment index, and Trade Payables.

Regarding other relationships, the most significant positive one can be found between Current assets and Trade Payables (0.74) as well as Equity (0.74), Turnover (0.74), and Working Capital (0.62). Another strong relationship was found between Equity and Working Capital (0.71), Turnover and Number of employees (0.68), or Turnover and Trade Payables (0.67). In terms of indirect relationship, the strongest one was found between Total Debt and Equity (-0.69) and Working Capital (-0.61). Mostly these correlations can be explained as a logical consequence of the similarity of indicators resulting from their interrelationships in the Balance Sheet. 
Table 2. Spearman's coefficient for tested indicators for micro and small enterprises in the Czech Republic $(2018, \mathrm{n}=2155)$

\begin{tabular}{|c|c|c|c|c|c|c|c|}
\hline variables & $\begin{array}{c}\text { GDP- } \\
\text { REG }\end{array}$ & $\begin{array}{r}\text { GDP- } \\
\text { NACE }\end{array}$ & N.EMP & $\begin{array}{r}\mathrm{N} . \\
\text { YEARS } \\
\end{array}$ & $\begin{array}{r}\text { REG. } \\
\text { CAP }\end{array}$ & TURN & $\begin{array}{r}\mathrm{P} . \\
\text { INDEX }\end{array}$ \\
\hline GDP-REG & 1 & -0.04 & -0.02 & -0.01 & -0.04 & -0.01 & 0.02 \\
\hline GDP-NACE & -0.04 & 1 & $*_{-} 0.10$ & 0.02 & -0.03 & $* 0.07$ & 0,00 \\
\hline N.EMP & -0.02 & $*_{-} 0.10$ & 1 & $* 0.29$ & $* 0.20$ & $* 0.68$ & 0.03 \\
\hline N.YEARS & -0.01 & 0.02 & $* 0.29$ & 1 & $*_{-} 0.08$ & $* 0.26$ & -0.02 \\
\hline REG.CAP & -0.04 & -0.03 & $* 0.20$ & $*-0.08$ & 1 & $* 0.24$ & 0.03 \\
\hline TURNOVER & -0.01 & $* 0.07$ & $* 0.68$ & $* 0.26$ & $* 0.24$ & 1 & $* 0.08$ \\
\hline PAYMENT.IN. & 0.02 & 0,00 & 0.03 & -0.02 & 0.03 & $* 0.08$ & 1 \\
\hline CURR.ASSETS & -0.04 & $* 0.09$ & $* 0.55$ & $* 0.44$ & $* 0.20$ & $* 0.74$ & $* 0.07$ \\
\hline EQUITY & -0.02 & 0.01 & $* 0.46$ & $* 0.47$ & $* 0.20$ & $* 0.55$ & $*_{-} 0.05$ \\
\hline TR.PAYABLES & 0,00 & $* 0.13$ & $* 0.45$ & $* 0.34$ & $* 0.27$ & $* 0.67$ & $* 0.18$ \\
\hline TOT.DEBT & 0,00 & $* 0.06$ & $*-0.12$ & $*-0.28$ & $*_{-} 0.04$ & $*_{-} 0.09$ & $* 0.15$ \\
\hline WORK.CAP. & -0.01 & 0.03 & $* 0.31$ & $* 0.31$ & $* 0.10$ & $* 0.40$ & $*-0.06$ \\
\hline $\mathrm{ROE}$ & 0.01 & -0.01 & -0.03 & $*_{-} 0.32$ & $*-0.06$ & 0.01 & -0.02 \\
\hline ROS & 0.03 & 0,00 & $* 0.12$ & 0.02 & 0.02 & $* 0.17$ & $*_{-} 0.07$ \\
\hline & $\begin{array}{r}\text { CURR. } \\
\text { ASSETS } \\
\end{array}$ & EQUITY & $\begin{array}{r}\text { TR. } \\
\text { PAYAB. }\end{array}$ & $\begin{array}{r}\text { TOT. } \\
\text { DEBT }\end{array}$ & $\begin{array}{r}\text { WORK. } \\
\text { CAP. }\end{array}$ & ROE & ROS \\
\hline GDP-REG & -0.04 & -0.02 & 0,00 & 0,00 & -0.01 & 0.01 & 0.03 \\
\hline GDP-NACE & $* 0.09$ & 0.01 & $* 0.13$ & $* 0.06$ & 0.03 & -0.01 & 0,00 \\
\hline N.EMP & $* 0.55$ & $* 0.46$ & $* 0.45$ & $*_{-} 0.12$ & $* 0.31$ & -0.03 & $* 0.12$ \\
\hline N.YEARS & $* 0.44$ & $* 0.47$ & $* 0.34$ & $*_{-} 0.28$ & $* 0.31$ & $*_{-} 0.32$ & 0.02 \\
\hline REG.CAP & $* 0.20$ & $* 0.20$ & $* 0.27$ & $*-0.04$ & $* 0.10$ & $*_{-} 0.06$ & 0.02 \\
\hline TURNOVER & $* 0.74$ & $* 0.55$ & $* 0.67$ & $*-0.09$ & $* 0.40$ & 0.01 & $* 0.17$ \\
\hline PAY.INDEX & $* 0.07$ & $*-0.05$ & $* 0.18$ & $* 0.15$ & $*-0.06$ & -0.02 & $*_{-0.07}$ \\
\hline CURR.ASSETS & 1 & $* 0.74$ & $* 0.74$ & $*_{-0.23}$ & $* 0.62$ & $*_{-} 0.06$ & $* 0.26$ \\
\hline EQUITY & $* 0.74$ & 1 & $* 0.46$ & $*-0.69$ & $* 0.71$ & $*_{-} 0.14$ & $* 0.39$ \\
\hline TR.PAYABLES & $* 0.74$ & $* 0.46$ & 1 & $* 0.09$ & $* 0.27$ & -0.04 & -0.01 \\
\hline TOT.DEBT & $*_{-0.23}$ & $*-0.69$ & $* 0.09$ & 1 & $*_{-} 0.61$ & $* 0.19$ & $*_{-} 0.41$ \\
\hline WORK.CAP. & $* 0.62$ & $* 0.71$ & $* 0.27$ & $*-0.61$ & 1 & $*_{-} 0.08$ & $* 0.33$ \\
\hline ROE & $*_{-}-0.06$ & $*_{-} 0.14$ & -0.04 & $* 0.19$ & $*-0.08$ & 1 & $* 0.40$ \\
\hline ROS & $* 0.26$ & $* 0.39$ & -0.01 & $*_{-} 0.41$ & $* 0.33$ & $* 0.40$ & 1 \\
\hline
\end{tabular}

\section{Conclusion}

The aim of the paper was to statistically test selected indicators in order to prove which of them have mutual relationship with selected performance indicators. This relationship indicates possible ability of the indicator to influence performance indicators (ROS, ROE), and thus the performance itself. It was important to find out whether there are any mutual relations between examined indicators, and whether these relations are not caused only by the use of indicators that are similarly constructed.

The results showed the mutual relationship between several indicators and ROE/ROS. However, it is necessary to keep in mind that proved correlation does not automatically 
imply causation [19]. For example, the correlation may be caused by a third unknown phenomenon that affects both indicators or may be opposite to what the researcher predicts (e.g. in this case the relationship between ROS and Total Debt may be caused by the fact, that the higher the profitability of sales is, the lower is the total debt). It is therefore necessary to take this fact into account when evaluating the results.

A statistically significant correlation was found between ROS and Total Debt $(-0.41)$, Equity (0.39), Working Capital (0.33) as well as Current Assets (0.26). As for ROE only one stronger correlation was found with Number of years in business $(-0.32)$, which has no logical explanation. These correlations can be partly explained by the mutual relationships of indicators resulted from interrelationships in Balanced Sheet Statement. However, partly they can imply real relationship, even causality. If the possible causality was admitted, the conclusions would not be illogical, for example the enterprises wishing to increase their performance would be advised to focus on reducing Total Debt, increasing Equity (which includes Profit) or increase Current Assets. Proving causality, as another logical step in this area of research, would cause a great progress in the global issue of business performance.

The research was supported by the research project SGS-2020-015 "Research in selected areas of management and marketing of organizations in the context of demographic and technological changes" at the University of West Bohemia.

\section{References}

1. Cokins, G. (2009). Performance Management: integrating strategy execution, methodologies, risk, And Analytics. Hoboken, New Jersey: John Wiley \& Sons, Inc.

2. Rolstadås, A. (1998). Enterprise performance measurement. International Journal of Operations \& Production Management, 18(9/10), 989-999.

3. Kaplan, R.S., Norton, D.P. (1996). The balanced scorecard: translating strategy into action. Boston: Harvard Business Review Press.

4. Cicea, C., Popa, I., Marinescu, C., Stefan, S. (2019). Determinants of SMEs' performance: Evidence from european countries. Economic Research-Ekonomska Istrazivanja, 32(1), 1602-1620.

5. Escribá-Esteve, A., Sánchez-Peinado, L., Sánchez-Peinado, E. (2009). The influence of top management teams in the strategic orientation and performance of small and medium-sized enterprises. British Journal of Management, 20(4), 581-597.

6. Ausloos, M., Cerqueti, R., Bartolacci, F., Castellano, N. G. (2018). SME investment best strategies. Outliers for assessing how to optimize performance. Physica A: Statistical Mechanics and its Applications, 509, 754-765.

7. Cataldo, A., Pino, G., McQueen, R.J. (2020). Size matters: The impact of combinations of ICT assets on the performance of chilean micro, small and medium enterprises. Information Technology for Development, 26(2), 1-24.

8. Skokan, K, Pawliczek A., Piszczur R. (2013). Strategic Planning and Business Performance of Micro, Small and Medium-Sized Enterprises. Journal of Competitiveness, 5(4), 57-72.

9. Podhorska, I., Siekelova, A. (2020). Enterprises Financial Performance in a Globalized World. SHS Web of Conferences, 74, 05018.

10. Švárová, M., Vrchota, J. (2013). Strategic management in micro, small and mediumsized businesses in relation to financial success of the enterprise. Acta Universitatis Agriculturae Et Silviculturae Mendelianae Brunensis, 61(7), 2859-2866. 
11. Dale-Olsen, H., Schone, P., Verner, M. (2013). Diversity among Norwegian boards of directors: Does a quota for women improve firm performance? Feminist Economics, $19,110-135$.

12. Pletzer, J.L., Nikolova, R., Kedzior, K.K., Voelpel, S.C. (2015). Does gender matter? Female representation on corporate boards and firm financial performance-A metaanalysis. PloS One, 10(6).

13. Sumedrea, S. (2016). Gender diversity and firm performance in seeking for sustainable development. Bulletin of the Transilvania University of Brasov. Series V: Economic Sciences, 9(2), 369-384

14. Marinova, J., Plantenga, J., Remery, C. (2016). Gender diversity and firm performance: Evidence from Dutch and Danish boardrooms. The International Journal of Human Resource Management, 27(15), 1777-1790.

15. Alpkan, L., Yilmaz, C., Kaya, N. (2007). Market orientation and planning flexibility in SMEs. International Small Business Journal, 25(2), 152.

16. Anggadwita, G., Mustafid, Q.Y. (2014). Identification of factors influencing the performance of small medium enterprises (SMEs). Procedia, Social and Behavioral Sciences, 115, 415-423.

17. Bisnode (2020). Database Albertina - Gold Edition, Praha: Bisnode, a. s.

18. Reguera-Alvarado, N., de Fuentes, P., Laffarga, J. (2017). Does board gender diversity influence financial performance? Evidence from Spain. Journal of Business Ethics, 141(2), 337-350.

19. Pearl, J. (2009). Causality: Models, reasoning, and inference (2nd ed.). New York: Cambridge University Press. 